УДК $662.995: 662.997$

DOI

\title{
CHOICE CRITERIA OF ADSORBENTS FOR HEAT ENERGY CONVERTERS IN VENTILATION SYSTEMS
}

Belyanovskaya E.A. ${ }^{1}$, PhD, docent, Lytovchenko R.D. ${ }^{1}$, postgraduate student, Sukhyy K.M. ${ }^{1}$, SciD, Prof., Prokopenko O.M. ${ }^{2}$ PhD, docent Yeromin O.O. ${ }^{2}$, SciD, Prof., Sukha I.V.', PhD, docent

${ }^{1}$ State Higher Education Institution «Ukrainian State University of Chemical Engineering», Dnipro, Ukraine

${ }^{2}$ National metallurgical academy of Ukraine, Dnipro, Ukraine

\begin{abstract}
The criteria of adsorbent selection for adsorption transformers of thermal energy in ventilation systems are considered. The main characteristics of adsorbents that affected the structural parameters of the adsorption module are revealed. The method of determining the mass of the adsorbent and the volume of the adsorption unit in ventilation systems has been developed. The main factor affecting the volume of adsorbent is confirmed to be maximal adsorption. The advantages of 'salt in the porous silica gel matrix' composites are compared with traditional silica gels. On the example of an adsorption regenerator of low-potential heat and moisture, the greater effectiveness of the composites "silica gel-sodium sulphate" is shown in comparison with the composite 'silica gel - sodium acetate'. According to the experimental data on the operation of the adsorption regenerator of heat and moisture on the basis of the composite 'silica gel $-\mathrm{CH}_{3} \mathrm{COONa}$ ', the adequacy of the proposed algorithm for determining the temperature efficiency factor has been confirmed.

Suggested algorithm includes the calculation of the air volume passed through the layer of heat-storage material, water concentration in the air at the exit from the heat accumulator, adsorption, heat of adsorption, the final cold air temperature, air temperature after mixing cold air from the street and the warm air in the room at the inlet, the calculation of the concentration of water in the flow at the exit from the heat regenerator, the adsorption and heat of adsorption, the final temperature of the warm air, the air temperature after mixing the cold air from the street and the warm air from the room during the discharge, determination of the temperature efficiency factor, total adsorption and time to achieve the maximal adsorption. The efficiency of the processes of operating adsorption regenerators based on composites 'silica gel-sodium sulphate' and 'silica gel-sodium acetate' in the conditions of the typical ventilation system of housing premises was compared.

The parameters that correspond to the maximum value of the temperature efficiency factors: the humid air velocity is about $0.22-0.32 \mathrm{~m} / \mathrm{s}$ and the time of switching of the flows up to 5 minutes. The influence of meteorological conditions on the efficiency of the adsorption regenerator has been confirmed. The higher efficiency of adsorption regenerators based on 'silica gel - sodium sulphate' composites is explained, which is explained by higher values of maximal adsorption, which results in increasing the heat of adsorption. The results of the research can be used for the selection of adsorbents for energy-efficient heat energy converters in ventilation systems for residential and warehouse premises.
\end{abstract}

Key words: adsorptive heat energy converter, heat-moisture regenerator, temperature efficiency coefficient, composite adsorbent.

\section{КРИТЕРІЇ ВИБОРУ АДСОРБЕНТІВ ДЛЯ ПЕРЕТВОРЮВАЧІВ ТЕПЛОВОЇ ЕНЕРГІї В СИСТЕМАХ ВЕНТИЛЯЦІї}

Бєляновська О.А. ${ }^{1}$, канд. техн. наук, доцент, Литовченко Р.Д. ${ }^{1}$, аспірант,

Сухий К.М. ${ }^{1}$, д-р техн. наук, професор, Прокопенко О.М. ${ }^{2}$, канд. техн. наук,

Єрьомін O.О. ${ }^{2}$, д-р техн. наук, професор, Суха І.В. ${ }^{1}$, канд. техн. наук, доцент

${ }^{1}$ ДВНЗ «Український державний хіміко-технологічний університет», м. Дніпро

${ }^{2}$ Національна металургійна академія України, м. Дніпро

\begin{abstract}
Анотація. Розглянуто критерії підбору адсорбентів для адсорбиійних перетворювачів теплової енергії в системах вентиляції. Виявлено основні характеристики адсорбентів, які впливають на конструктивні параметри адсорбиійного модуля. Розроблено методику визначення маси адсорбента та об 'єму адсорбиійного модуля в системах вентиляиіі. Підтверджено, що основним фактором, який впливає на об 'єм адсорбенту є його максимальна адсорбція. Показані переваги композитів «сіль в поринній матриці силікагелю» в порівнянні з традиційними силікагелями. На прикладі адсорбиійного регенератора на основі низькопотенційної теплоти та вологи показана більша ефективність композитів «силікагель - натрій сульфат» в порівнянні композитом «силікагель - натрій ацетат».
\end{abstract}

Наукові праці, Том 83, випуск 1 Scientific Works, Volume 83, Issue 1 
На основі експериментальних даних з експлуатації адсорбиійного регенератора теплоти та вологи на основі композиту 'силікагель - $\mathrm{CH}_{3} \mathrm{COONa}$ ' підтверджена адекватність запропонованого алгоритму визначення температурного коефіцієнту корисної дї̈, який включає розрахунок об'єму повітря, який пройшов через шар теплоакумулюючого матеріалу, концентрації води в повітрі на виході з регенератора, адсорбції, теплоти адсорбиії, кінцевої температури холодного повітря, температури повітря після змішування холодного повітря з вулиці та теплого повітря в приміщенні при подачі, розрахунок концентрації води в повітрі на виході з теплового акумулятора, об'єму повітря, який пройшов через шар теплоакумулюючого матеріалу, адсорбиії та теплоти адсорбиії, кінцевої температури теплого повітря, температури повітря після змішування холодного повітря з вулииі та теплого повітря з приміщення при викиді, визначення температурного коефіиієнта корисної діï, сумарної адсорбиії та часу досягнення максимальної адсорбиії.

Порівняна ефективність процесів експлуатаџії адсорбиійних регенераторів на основі композитів «силікагель - натрій сульфат» та «силікагель - натрій ацетат» в умовах типової системи вентиляції житлових приміщень. Встановлені параметри, які відповідають максимальним значенням температурних коефіиієнтів корисної дї: швидкості вологого повітря близько 0,22 - 0,32 м/с та час перемикання потоків до 5 xв..

Підтверджено вплив метеорологічних умов на ефективність адсорбиійного регенератора. Показана більи висока ефективність адсорбиійних регенераторів на основі композитів «силікагель - натрій сульфат», яка пояснена більш високими значеннями максимальної адсорбиії, щзо сприяє підвищенню теплоти адсорбиії. Результати проведеного дослідження можуть бути використані при підборі адсорбентів для енергоефективних перетворювачів теплової енергї в вентилячійних системах для житлових та складських приміщень.

Ключові слова: адсорбційний перетворювач теплової енергії, регенератор тепла та вологи, температурний коефіцієнт корисної дії, композитний адсорбент.

Introduction. Rising of global energy markets in 2017 accompanied by an increase of $2.2 \%$ in energy demand, resulting in a corresponding rise of $1.6 \%$ in carbon emissions [1]. A crucial expenditure item in the operation for ventilation and heat supply systems in Ukraine is heating load of the inflow air. Regenerative units for ventilation systems such as rotary heat exchanger, static heat exchanger and enthalpy wheels [2, 3] reveal not only fresh air pollution resulted from constant change of air direction, but the lack of separate air control. Traditional domestic ventilation and air conditioning systems based on steam compression machines occur to demand on significant electric load.

Adsorptive heat energy conversion is shown by numerous studies to be promising technology for the regeneration of heat and moisture and heat energy storage for heat supply and ventilation system [4 - 6]. However, design and performance of such systems based on adsorptive units are strongly determined by properties of adsorbents used. Adsorptive properties of composite 'salt in porous matrix' are known to depend on chemical nature of salt and matrix, porous structure of matrix and size of dispersed salt particles which resulted in kinetic of adsorption $[6,7]$.

Obviously, values of adsorption heat and volumes of adsorptive units are strongly affected by adsorptive capacities of applied materials [8]. Potentials of probable heat sources are strictly limited by regeneration temperatures of adsorbents [4]. So, detailed study of correlation of adsorbent characteristic and operating parameters of adsorptive heat conversion device is essential.

The purpose of the presented work is to establish the criteria of choice of adsorbent for heat conversion units in the ventilation systems. To accomplish this aim, the following tasks are set:

- to reveal basic characteristics of adsorbents affecting the constructional characteristic of adsorptive conversion unit;

- to determine correlation between design parameters, adsorbent properties and operating parameters of adsorptive conversion unit;

- to formulate the basic requirements to adsorbents for ventilation systems based on adsorptive heat conversion.

Experimental. The present work is focused on corellation of adsorbent propreties and the constructional and operational characteristics of the adsorptive heat-moisture regenerator. Its design is presented in Fig. 1 [5]. 
Length of laboratory prototype of heat regenerator is $0.6 \mathrm{~m}$. As heat storage material composite adsorbents 'silica gel - sodium sulphate' and 'silica gel sodium acetate' were used. Sol - gel technique of their synthesis is described in [5]. The

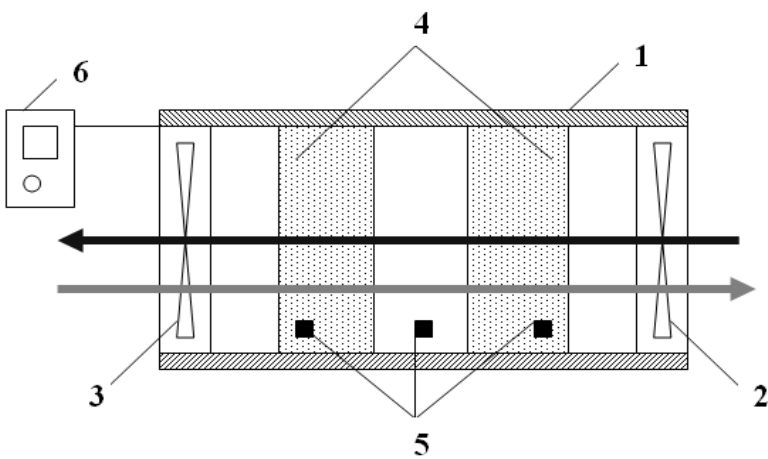

Fig.1. Heat regenerator construction

1 - pipe (case); 2 - external ventilator; 3 - inner ventilator; 4 - heat storage checkerworks; 5 - temperature detector; 6 - operating console [5]. device operational regimes are 'inflow' and 'outflow' which alternate one to another [5].

The outer end of investigated device is considered to be cold, the end placed in ventilated premise being warm. Estimation of structural characteristics of adsorptive regenerator is based on calculation of load for inflow air-heating per a day $\mathrm{Q}_{\text {inf }}$ by traditional procedure according the Sanitary Regulations 2.04.05-91:

$$
\mathrm{Q}_{\text {inf }}=0,28 \times \mathrm{L}_{\text {inf }} \times \mathrm{P}_{\text {air }} \times \mathrm{c} \cdot\left(\mathrm{t}_{\text {in }}-\mathrm{t}_{\text {ext }}\right) \cdot \tau
$$

where $\mathrm{L}_{\text {inf }}$ is inflowing air consumption, $\mathrm{m}^{3}$ per hour; $\rho_{\text {air }}$

2 is density of inner air, $\mathrm{kg} / \mathrm{m}^{3}$; $\mathrm{c}$ is specific heat of air, $\mathrm{kJ} /\left(\mathrm{kg} \cdot{ }^{\circ} \mathrm{C}\right) ; \mathrm{t}_{\mathrm{in}}$ is temperature of internal air, ${ }^{\circ} \mathrm{C} ; \mathrm{t}_{\mathrm{ext}}$ is temperature of external air, ${ }^{\circ} \mathrm{C}$; $\tau$ is operating period, hours per a day.

Then mass of adsorbent $\mathrm{M}_{\mathrm{ads}}$, $\mathrm{kg}$ is calculated as [8]

$$
\mathrm{M}_{\mathrm{ads}}=\frac{\mathrm{Q}_{\text {inf }}}{\Delta \mathrm{H}_{\mathrm{ads}}}
$$

where $\Delta \mathrm{H}_{\mathrm{ads}}$ is heat of adsorption, $\mathrm{kJ} / \mathrm{kg}$ which estimated as $[8,9]$

$$
\Delta \mathrm{H}_{\mathrm{ads}}=\Delta \mathrm{h} \cdot \mathrm{A}_{\mathrm{lim}} \cdot \frac{1000}{\mathrm{H}_{\mathrm{H}_{2} \mathrm{O}}}
$$

where $\Delta \mathrm{h} \cong 60$ is heat adsorption of water vapour, $\mathrm{kJ} /$ mole; $\mathrm{A}_{\mathrm{lim}}$ is maximal adsorption, $\mathrm{kg} / \mathrm{kg}$; $\mu_{\mathrm{H}_{2} \mathrm{O}}$ is the molar mass of water, $\mathrm{g} / \mathrm{mole}$.

The value of $\mathrm{A}_{\mathrm{lim}}$ can be determined according to adsorbent characteristics or estimated as linear superposition for mechanical mixture [9]. Volume of an adsorbent is calculated as a ratio of adsorbent mass and adsorbent density according to [8].

As efficiency criterion of adsorptive heat-moisture regenerator temperature efficiency factor or heat regeneration coefficient $\eta_{\text {tem }}$ was used. It was determined by algorithm (Fig. 2).

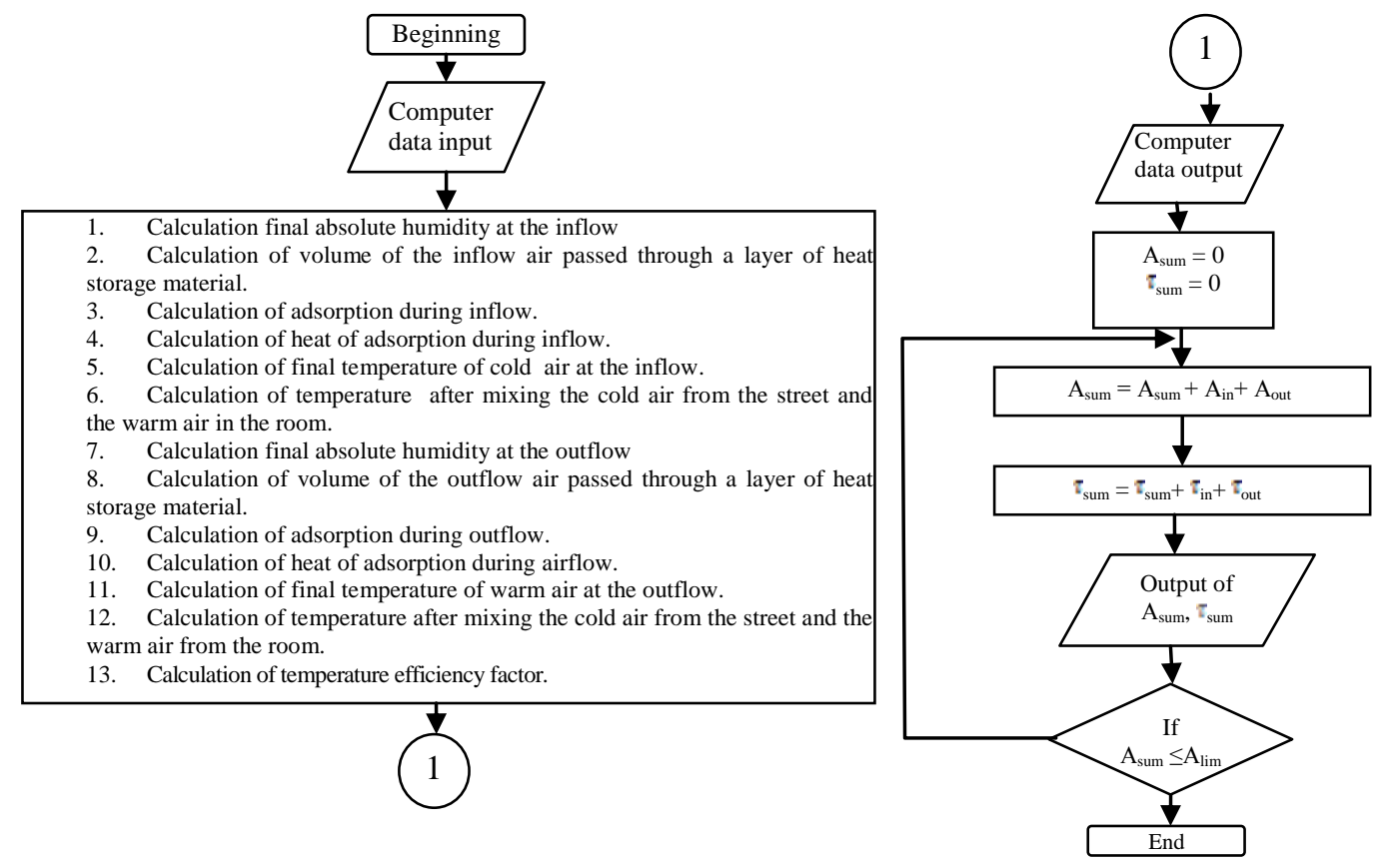

Fig. 2. Control-flow chart for calculation of efficiency factor of adsorptive regenerator [5] 
Results and discussion

Results of calculation of mass of adsorbents are given in Table 1.

Adsorption heat and adsorbent mass and volume for heat load

Table 1 to inflow air heating of 327.9 $\mathrm{MJ}$ per a day

\begin{tabular}{|l|c|c|c|c|c|c|}
\hline \multicolumn{1}{|c|}{ Adsorbent } & $\begin{array}{c}\text { Max- } \\
\text { imal } \\
\text { ad- } \\
\text { sorp- } \\
\text { tion } \\
\mathrm{A}_{\text {lim, }} \\
\mathrm{kg} / \mathrm{kg}\end{array}$ & $\begin{array}{c}\text { Heat of } \\
\text { adsorption, } \\
\mathrm{kJ} / \mathrm{kg}\end{array}$ & $\begin{array}{c}\text { Adsor- } \\
\text { bent } \\
\text { mass, } \\
\mathrm{kg}\end{array}$ & $\begin{array}{c}\text { Adsor- } \\
\text { bent vol- } \\
\text { ume, } \mathrm{m}^{3}\end{array}$ & $\begin{array}{c}\text { Regenera- } \\
\text { tion tem- } \\
\text { perature, }{ }^{\circ} \mathrm{C}\end{array}$ & $\begin{array}{c}\text { Refer- } \\
\text { ences }\end{array}$ \\
\hline Silica gel KCM & 0.20 & 666.67 & 491.85 & 0.68 & 150 & {$[10]$} \\
\hline Silica gel Type 3A & 0.32 & 1066.67 & 307.41 & 0.42 & 100 & {$[11]$} \\
\hline Silica gel Type RD & 0.36 & 1200.00 & 273.25 & 0.35 & 100 & {$[11]$} \\
\hline $\begin{array}{c}\text { Silica gel (20\%) - sodium } \\
\text { sulphate (80\%) }\end{array}$ & 1.046 & 3486.67 & 94.0 & 0.13 & 90 & [7] \\
\hline $\begin{array}{c}\text { Silica gel (20 \%) - sodium } \\
\text { acetate (80 \%) }\end{array}$ & 0.557 & 1856.10 & 176.6 & 0.25 & 60 & [7] \\
\hline
\end{tabular}

Calculation results confirm that silica gels of domestic and foreign grades are inferior in adsorption heat to composite adsorbents by a factor of $1.5-20$. So, to support with the same heat load the more mass of silica gel is necessary as compared with composite adsorbents. The same ratio could be predicted for inputs of heat carriers. Obviously, potential of waste energy source is determined with regeneration temperatures of adsorbents. Regeneration temperatures of

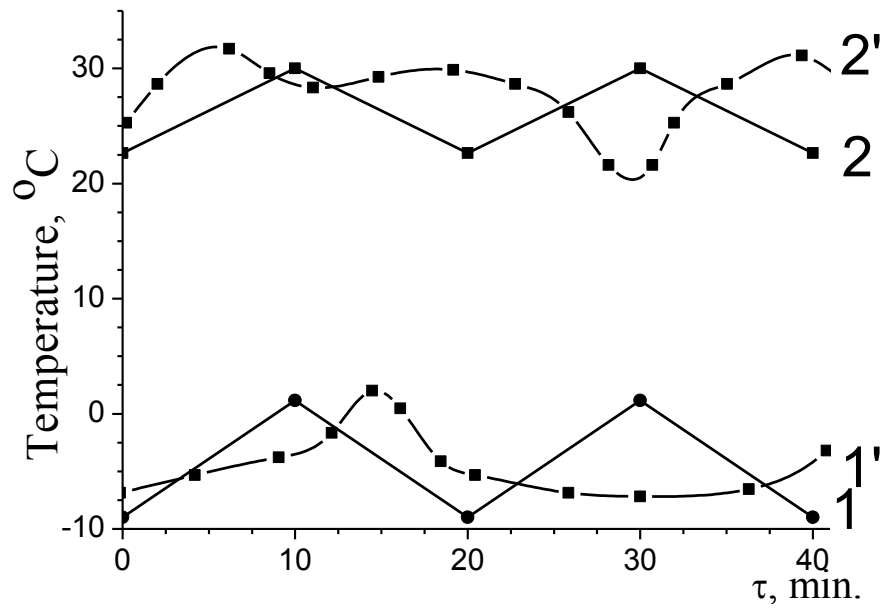

Fig. 3. Comparison of experimental and computed data for adsorptive heat regenerator based on composite 'silica gel - sodium acetate'. 1,2 - calculation results; 1', 2' - experimental data; 1, 1' - temperatures on cold end of regenerator; 2, 2' - temperatures on warm end of regenerator composite are substantially lower by contrast to traditional. The lower value of regeneration temperature is stated for composite 'silica gel - sodium acetate'. Nevertheless, its maximal adsorption or water capacity is $0.557 \mathrm{~kg} / \mathrm{kg}$, when $\mathrm{A}_{\text {lim }}$ for composite 'silica gel - sodium sulphate' exceeds it in nearly 2 times. The same ratio is stated for adsorption heats of studied composites. So, mass and volume of composite 'silica gel - sodium sulphate' required to fufill the same heat load is estimated to be half as much as compared with 'silica gel - sodium acetate' with the same content of salt.

Proposed algorithm was confirmed by experimental data for regenerator based on composite 'silica gel - sodium acetate' presented in [12]. The results of the calculations reveal the periodic dependence of the temperatures on the cold and warm ends of the adsorptive regenerator with (Fig. 3, curves 1 and 2), which qualitatively corresponds to the experimental data (Fig. 3, curves 1 'and 2').

The deviation of the calculated temperatures from the experimental does not exceed $2-2.5^{\circ} \mathrm{C}$ at the cold and warm ends of the regenerator. The temperature efficiency coefficient of the regenerator according to the experimental data is approximately $85 \%$, and according to the calculated approximately $82 \%$. So, this mathematical model can be used for qualitative evaluation of the performance characteristics of adsorptive regenerators in ventilation systems.

Then operating the adsorptive regenerators based on composites 'silica gel sodium - sulphate' and 'silica gel sodium acetate' was simulated for ventilation system in the conditions of a typical three-room apartment with electric cookers, a total area of $103 \mathrm{~m}^{2}$, a height of 2.5 meters. As an optimal option is to install in the scheme of 3- 
bedroom apartments four adsorptive regenerators, masses of adsorbents 'silica gel $-\mathrm{Na}_{2} \mathrm{SO}_{4}$ ' and 'silica gel $\mathrm{CH}_{3} \mathrm{COONa}$ ' on the regenerator are $24 \mathrm{~kg}$ and $45 \mathrm{~kg}$, respectively. According to results of calculation, decreasing time of switching (change of direction) flows results in a significant decrease in the amplitude of the periodical dependencies of temperature vs. switching time, both on the warm and the cold ends of the device. As a consequence, efficiency coefficients for both composites are stated to increase when the speed of the flow of humid air and the time of switching (change of direction) flows are decreased from 0.52 to $0.22 \mathrm{~m} / \mathrm{s}$ and from 20 to 5 minutes. Efficient factors are stated to rise as external temperature increased (Fig. 4).

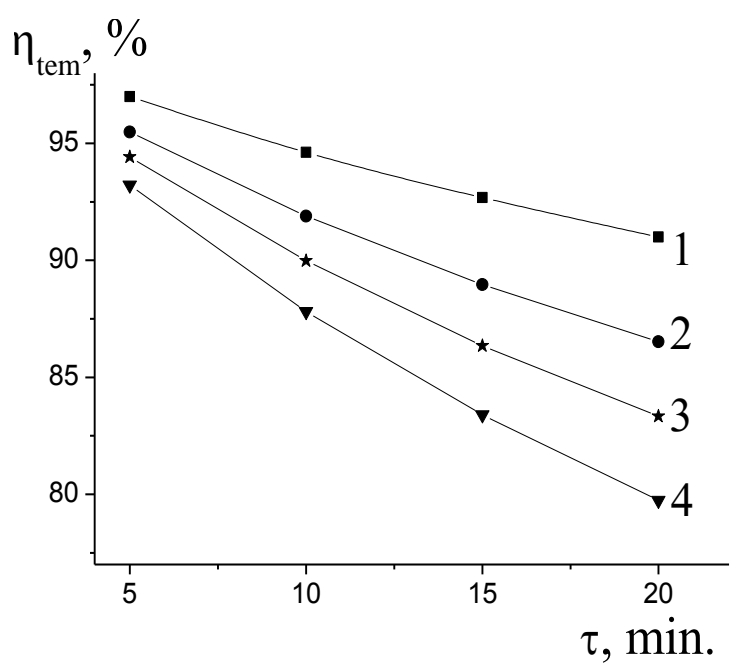

a

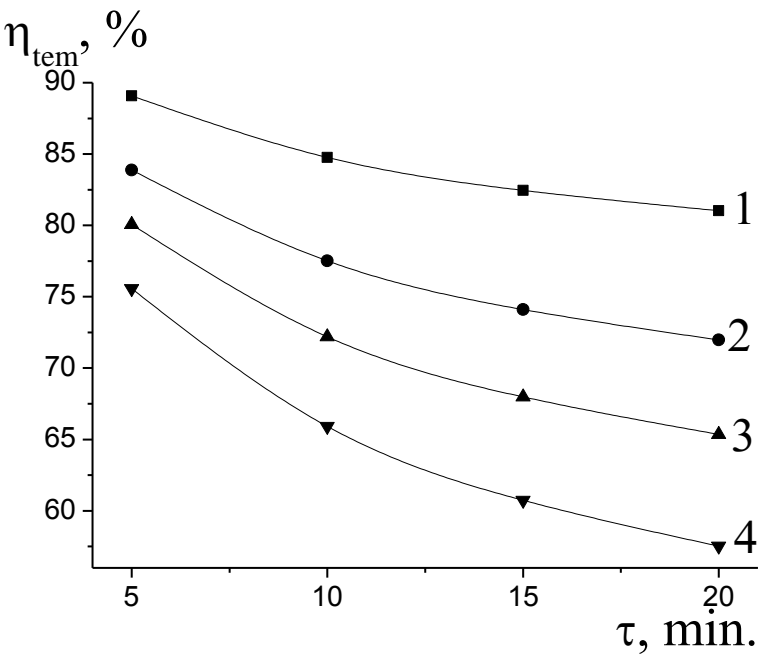

b

Fig. 4. Temperature efficiency coefficient-switching time for adsorptive regenerators based on 'silca gel sodium sulphate (a) and 'silica gel - sodium acetate' (b) at the temperatures of external air, ${ }^{\circ} \mathrm{C}: 1$ - -3; 2 - 9; $3-\mathbf{- 1 5} ; 4--25$.

When composite 'silica gel - sodium acetate' or 'silica gel - sodium sulphate' used, the maximum values of the temperature efficiency coefficients are observed at the flow rates of the moist air of $0.22-0.32 \mathrm{~m} / \mathrm{s}$ and the time of switching the flows at most of about $5 \mathrm{~min}$. Temperature of external air does not affect the time to reach maximal adsorption. Similarly, temperature efficiency factor is affected by decreasing the internal temperature. When composite 'silica gel - sodium sulphate' or 'silica gel - sodium acetate' used, the highest values of temperature efficiency factor are stated at the temperatures of internal air of $15^{\circ} \mathrm{C}$. For both of considered composite maximal values of temperature efficiency factors are corresponded to the internal temperatures of $15-18^{\circ} \mathrm{C}$ and external temperatures $-5-0^{\circ} \mathrm{C}$.

Nevertheless, when 'silica gel - sodium sulphate' used, in all of studied conditions temperature efficiency coefficients of regenerator occur to exceed 'silica gel - sodium acetate' by more than $5 \%$. Such differences correlate with maximal values of adsorption of composite used.

Obviously, time to achieve the maximal values of adsorption is affected by the properties of adsorbents, the maximal adsorption being crucial factor. Maximal time to achieve the maximal adsorption for both adsorbents is stated at the airflow rates at most of $0.22 \mathrm{~m} / \mathrm{s}$ which corresponded to minimal volumes of the delivered air (Table 2).

Time to achieve the maximal adsorption-airflow rate relationship

\begin{tabular}{|c|c|c|c|c|}
\hline \multirow{2}{*}{ Composite } & \multicolumn{3}{|c|}{ Time to achieve the maximal adsorption, $\mathrm{h}$} \\
& \multicolumn{4}{|c|}{ at the airflow rate, $\mathrm{m} / \mathrm{s}$} \\
\cline { 2 - 5 } & 0.22 & 0.32 & 0.42 & 0.52 \\
\hline $\begin{array}{c}\text { Silica gel (20\%)- } \\
\text { sodium sulphate (80\%) }\end{array}$ & 135 & 97.5 & 82.0 & 67.5 \\
\hline $\begin{array}{c}\text { Silica gel }(20 \%)- \\
\text { sodium acetate }(80 \%)\end{array}$ & 125 & 87 & 69 & 57 \\
\hline
\end{tabular}


Furthermore, the higher values of time to achieve the maximal adsorption is registered for composite 'silica gel sodium sulphate' that agrees with the ratio of the maximal adsorption for the considered materials.

So, as criteria to choice adsorbents for heat-moisture regenerator for can be considered the maximal adsorption and regeneration temperature. The crucial factor of them seems to be maximal values of adsorption or water capacity which determines heats of adsorption.

Conclusions. Adsorbent characteristics and performance of adsorptive heat-moisture regenerator was studied. The method of determination of the main design characteristics of the adsorptive unit in the conditions of the ventilation system for the residential premises is developed. The correlation between mass of adsorptive unit and maximal adsorption is shown. Advantages of composites 'salt inside of porous matrix' are established as compared with traditional adsorbents. Composite adsorbents 'silica gel $-\mathrm{Na}_{2} \mathrm{SO}_{4}$ ' and 'silica gel $-\mathrm{CH}_{3} \mathrm{COONa}$ ' are confirmed as perspective materials for heat and moisture regeneration in ventilation systems due to lower value of necessary mass. Maximal adsorption is stated to be crucial factor to choice an adsorbent because of determining mass and volume of adsorptive unit.

Performance parameters of adsorptive regenerators based on composite 'silica gel $-\mathrm{Na}_{2} \mathrm{SO}_{4}$ ' and 'silica gel $\mathrm{CH}_{3} \mathrm{COONa}$ ' were compared. The highest temperature efficiency factors are stated at flow rates of the moist air of $0.22-0.32 \mathrm{~m} / \mathrm{s}$ and the time of switching the flows at most of about $5 \mathrm{~min}$. The growth of the efficiency coefficient is stated as the temperature of the external air increased from $-25^{\circ}$ to $-3^{\circ} \mathrm{C}$. The efficiency of regenerators based on 'silica gel $-\mathrm{Na}_{2} \mathrm{SO}_{4}$ ' and 'silica gel $-\mathrm{CH}_{3} \mathrm{COONa}$ ' was compared. Higher performance of regenerators based on 'silica gel $-\mathrm{Na}_{2} \mathrm{SO}_{4}$ ' is shown to result from higher value of maximal adsorption.

This work was supported by Ministry of Education and Science of Ukraine (grant number 0119U002243).

\section{References}

1. Xue, B., Ye, S., Zhang, L., Wei, X., Nakaso, K., Fukai, J. (2019). High-temperature steam generation from low-grade waste heat from an adsorptive heat transformer with composite zeolite-13X/CaCl 2 . Energy Conversion and Management. 186, 93 - 102. https://doi.org/10.1016/j.enconman.2019.02.040

2. Ashrae (2012) Ashrae Handbook Heating, Ventilating, And Air-Conditioning systems and equipment (2012). Athlanta, 1081

3. Fu, H., Liu, X., Xie, Y., Jiang, Y. (2019). Experimental and numerical analysis on total heat recovery performance of an enthalpy wheel under high temperature high humidity working conditions. 146, $482-494$.

4. Sukhyy, K.M., Belyanovskaya, E.A., Kolomiyets, E.V. (2018). Design and performance of adsorptive transformers of heat energy. Riga, Latvia: LAP Lambert Academic Publishing, 117

5. Belyanovskaya, E.A., Lytovchenko, R.D., Sukhyy, K.M., Sukhyy, M.P., Gubinskyi, M.V. (2018). Performance characteristics of adsorptive regenerator of low-potential heat and moisture based on composite adsorbents 'silica gel - sodium sulphate' synthesized by sol - gel method. Scientific works OHAFT. 82 (1), 37 - 41

6. Aristov, Yu.I., Gordeyeva, L.G., Tokarev, M.M. (2008). Kompositnyie sorbenty 'sol v porakh matritsy': syntez, svoystva, primeneniye. Novosibirsk, Russia, SO RAN, 362 (in Russian)

7. Sukhyy, K., Belyanovskaya, E., Kovalenko, V., Kotok, V., Sukhyy, M., Kolomiyets, E., Gubynskyi, M., Yeromin, O., Prokopenko, O. (2018). The study of properties of composite adsorptive materials "silica gel - crystalline hydrate" for heat storage devices. Eastern-European Journal of Enterprise Technologies. 91(1), 52 - 58.

8. Sukhyy, K.M., Komiyets, O.V., Prokopenko, O.M., Gavrilko, A.V., Belyanovska, O.A. (2017). Algoritm rozrakhunku obyemu adsobtsiynogo tepolovogo akkumulyatora dlya systemy detcentralizovanogo opalyuvannya. Kompyuterne modeluvannya, analyz, upravlinnya, optimizatsiya. Zbirnyk naukovykh prats, 72 - 76 (in Ukrainian)

9. Kolomiyets, O.V. (2015) Pidvyshchennya efektyvnosti adsorbtsiynykh peretvoryuvachiv teplovoyi enerhiyi za rakhunok vykorystannya novykh kompozytnykh sorbentiv (Cand. tech. sciences). Retrieved from Dissertations and Theses database. (UMI No. PA430247) (in Ukraine)

10. State Standard 3956-76. Silica gel for industrial use. Specifications. M., Publishing Office of State Standards, 13 .

11. Ng, K.C., Chua, N.T., Chung, C.Y., Loke, C.H., Kasiwagi, T., Akisawa, A., Saha, B.B. (2001). Experimental investigation of silica gel water adsorption isotherm characteristics. Applied Thermal Engineering. 21, 1631 $-1642$

12. Kolomiyets, O. V., Sukhyy, K. M., Belyanovskaya, E. A., Tomilo, V. I., Prokopenko, O. M. (2016). Operating characteristics of adsorptive regenerator of low-potential heat and moisture based on composite sorbents 'silica gel - sodium sulphate and silica gel - sodium acetate' synthesized by sol - gel method. Scientific works ONAFT, 80(1), $108-113$.

Отримано в редакцію 04.04.2019

Received 04.04.2019

Прийнято до друку 16.06.2019

Approved 16.06.2019 